\title{
Stability Indicating RP-HPLC Method for the Simultaneous Estimation of Pyrimethamine and Sulphadoxine in Bulk and Tablet Dosage Form
}

\author{
Veeragoni Anil Kumar ${ }^{1 *}$, Vasudeva Murthy Sindgi ${ }^{2}$, Shoba Rani Satla ${ }^{3}$, Manish Kumar Thimmaraju ${ }^{4}$ \\ ${ }^{1}$ Department of Pharmaceutical Analysis, Pathfinder institute of Pharmacy Education and Research, Warangal-Telangana. ${ }^{2}$ Jayamukhi College of Pharmacy, \\ Narsampet, Warangal, Telangana. ${ }^{3}$ Center for Pharmaceutical Sciences, Institute of Science and Technology, JNTUH, Hyderabad, Telangana. ${ }^{4}$ Central \\ Analytical Laboratory, Balaji Institute of Pharmaceutical Sciences, Narsampet, Warangal-Telangana.
}

\section{ARTICLE INFO \\ Article history: \\ Received on: 24/12/2015 \\ Revised on: 15/01/2016 \\ Accepted on: 08/02/2016 \\ Available online: 30/03/2016}

\section{Key words:}

Pyrimethamine,

sulphadoxine, ICH guidelines

and stress degradation

studies.

\begin{abstract}
A stability indicating simple, selective, accurate high Performance Liquid Chromatographic (HPLC) method was developed and validated for the combined tablet formulation of pyrimethamine \& sulphadoxine. Chromatographic separation was optimized by gradient HPLC on a C18 column [Inertsil Silica, $250 \mathrm{x} 4.6 \mathrm{~mm}$, $5 \mu$ ] utilizing a mobile phase of potassium dihydrogen phosphate and acetonitrile taken in the ratio 70:30 at a flow rate of $1.0 \mathrm{ml} / \mathrm{min}$ with UV detection at $221 \mathrm{~nm}$. The retention time of pyrimethamine and sulphadoxine was 2.77 and 6.57 min respectively. The developed method was validated in terms of accuracy, precision, linearity, limit of detection, limit of quantitation, robustness and stress degradation studies. Validation of the method was done in accordance with ICH guidelines for the assay of active ingredients. Thus validated method can be recommended for the routine laboratory analysis.
\end{abstract}

\section{INTRODUCTION}

Pyrimethamine is an anti-malarial drug which inhibits the dihydrofolatereductase of plasmodia and there by blocks the biosynthesis of purines and pyrimidines, which are essential for DNA synthesis and cell multiplication. Sulfadoxine is a sulfa drug, often used in combination with pyrimethamine to treat malaria. Review of literature for pyrimethamine \& sulphadoxine gave information regarding the various studies conducted and analytical methods established for the drugs alone, in combination and in combination with other drugs in pharmaceutical dosage forms and in biological fluids (Minzi et al., 2013, Sinnaeve et al., 2005). There are few methods reported in the literature for analysis of pyrimethamine $\&$ sulphadoxine alone or in combination with other drugs in the pure form, pharmaceuticals formulations and biological fluids by UVspectrophotometer (Onah and Odeiani, 2002, Meena and

\section{* Corresponding Author}

Veeragoni Anil Kumar, Department of Pharmaceutical Analysis Pathfinder Institute of Pharmacy Education And Research, WarangalTelangana.Email: v_aneel@yahoo.co.in
Sandhya, 2013), HPTLC (Meena and Sandhya, 2013), Capillary zone electrophoresis (Amin et al., 2012), RP-HPLC (Green et al., 2002, Bergqvist et al., 1991; Astier et al., 1997; Bergqvist et al., 1985; SaeedArayne et al., 2010), LC-MS (Sinnaeve et al., 2005).

There was no stability indicating HPLC methods established for the simultaneous estimation of pyrimethamine \& sulphadoxine in formulation. The aim of the present work is to develop a stability indicating analytical method for the combined tablet formulation of pyrimethamine \& sulphadoxine. Validation of the method was done in accordance with ICH guidelines for the assay of active ingredients. Thus validated method can be recommended for the routine laboratory analysis.

\section{MATERIALS AND METHODS}

Pyrimethamine (PYR) and Sulphadoxine (SUL) were procured as gift samples from Taj pharmaceuticals, Mumbai. REZIZ (Pyrimethamine -25mg and Sulphadoxine - 500mg) tablets manufactured by Shreya life sciences pvt. Ltd. India was procured from a local pharmacy. Acetonitrile (HPLC grade), ortho phosphoric acid, Potassium dihydrogen ortho phosphate, Methanol (HPLC grade), Tri ethyl amine and TDW (Triple Distilled Water). 


\section{Instrumentation}

Shimadzu gradient HPLC MODEL NO (JAPAN), HPLC column Inertsil $(250 \times 4.6 \mathrm{~mm}, 5 \mu \mathrm{m})$, Mobile phase filtration unit (Pall Life sciences, Mumbai, India), LAB-INDIA U.V with UV Win software, Sonicator, $\mathrm{P}^{\mathrm{H}}$ meter (LAB-INDIA), digital balance (Denver).

\section{METHOD DEVELOPMENT}

\section{Preparation of standard solutions}

Accurately weighed and transferred $10 \mathrm{mg}$ of Pyrimethamine and $10 \mathrm{mg}$ of Sulphadoxine working Standards into two separate $100 \mathrm{ml}$ clean dry volumetric flasks, add $30 \mathrm{ml}$ of diluent, sonicated for 5 minutes and make up to the final volume with diluent.

\section{Chromatographic Conditions}

The HPLC system consisted of Shimadzu gradient HPLC (JAPAN) with dual $\lambda$ Absorbance UV detector. The wavelength of detection as set at $221 \mathrm{~nm}$. Separation was carried out in gradient mode on inertsil $\mathrm{C} 18$ column $(4.6 \times 250 \mathrm{~mm} \times 5 \mu \mathrm{m})$ and the retention time of pyrimethamine and sulphadoxime was found to be 2.952 and 6.832 respectively (figure 1), using 70:30 v/v dihydrogen orthophosphate : acetonitrile as mobile phase at a flow rate of 1 $\mathrm{ml} / \mathrm{min}$. The mobile phase filtered through nylon milli pore $(0.2 \mu \mathrm{m})$ membrane filter, purchased from pall life sciences, Mumbai and degassed with Ultrasonicator prior to use. Chromatography was carried out at room temperature $25^{\circ} \mathrm{c}$ and maintains the column temperature at $32^{\circ} \mathrm{c}$.

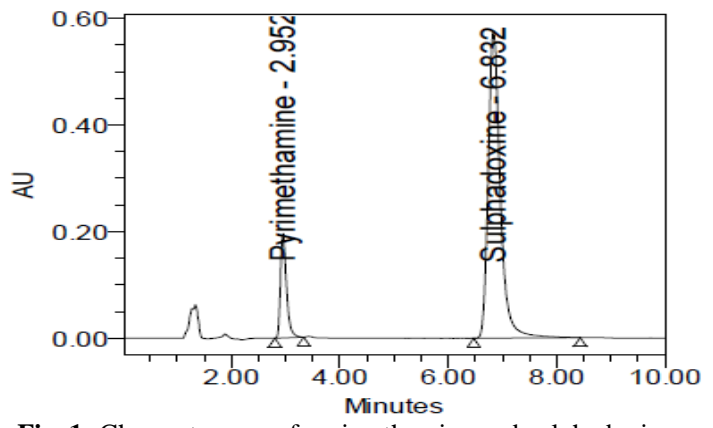

Fig. 1: Chromatogram of pyrimethamine and sulphadoxime.

\section{Preparation of Standard Solutions}

Stock solutions of pyrimethamine $(0.5 \mathrm{mg} / \mathrm{ml})$ and sulphadoxime $(1 \mathrm{mg} / \mathrm{ml})$ were prepared in methanol. Further dilutions were carried out in $60 \%$ acetonitrile and calibration standards were prepared freshly with pyrimethamine and sulphodoxime stock solutions to give the concentrations of 5, 10, $15,20,25$ and $30 \mu \mathrm{g} / \mathrm{ml}$.

\section{Sample Preparation (Assay)}

5 tablets were weighed and calculate the average weight of each tablet then the weight equivalent transferred into a $100 \mathrm{~mL}$ volumetric flask, $60 \mathrm{~mL}$ of diluent added and sonicated for $25 \mathrm{~min}$, further the volume made up with diluent and filtered. From the filtered solution $0.2 \mathrm{ml}$ was pipetted out into a $10 \mathrm{ml}$ volumetric flask and made upto $10 \mathrm{ml}$ with diluent.

\section{RESULTS \& DISCUSSIONS}

\section{Method Validation}

Method validation was performed as per the ICH guidelines Q2 (R1) Validation of Analytical Procedure. The developed method was validated for the following parameters.

\section{Linearity}

Linear concentrations of both drugs were prepared and the best fit line was calculated. Wide range calibration was determined by solutions containing $5 \mu \mathrm{g} / \mathrm{ml}$ to $30 \mu \mathrm{g} / \mathrm{ml}$ (table 1 ). Correlation coefficient was found to be $0.999 \& 0.997$ for Pyrimethamine \& Sulphadoxine respectively (shown in fig 2\&3).

Table 1: Linearity results of pyrimethamine \& sulphadoxine.

\begin{tabular}{ccccc}
\hline \multirow{2}{*}{ Sno } & \multicolumn{2}{c}{ Pyrimethamine } & \multicolumn{2}{c}{ Sulphadoxine } \\
\cline { 2 - 5 } & $\begin{array}{c}\text { Concentration } \\
(\boldsymbol{\mu g} / \mathbf{m l})\end{array}$ & Peak area & $\begin{array}{c}\text { Concentration } \\
(\boldsymbol{\mu g} / \mathbf{m l})\end{array}$ & Peak area \\
\hline 1 & 5 & 329102 & 5 & 2279923 \\
2 & 10 & 876684 & 10 & 5805764 \\
3 & 15 & 1225460 & 15 & 8254245 \\
4 & 20 & 1753561 & 20 & 11870562 \\
5 & 25 & 2109537 & 25 & 14481530 \\
6 & 30 & 2614420 & 30 & 18076428 \\
\hline
\end{tabular}

\section{Precision}

The intraday precision was demonstrated by injecting six test solutions at $25 \mu \mathrm{g} / \mathrm{ml}$ concentration as per the test procedure (shown in table no $2 \& 3$ ) \& recording the chromatograms of six test solutions. The \% RSD of pyrimethamine and sulphodixime was found to be 0.207 and 0.324 respectively.

Table 2: Method Precision of Pyrimethamine.

\begin{tabular}{cccc}
\hline \multirow{2}{*}{ Sno } & \multicolumn{3}{c}{ Pyrimethamine $(\mathbf{2 5} \boldsymbol{\mu g} / \mathbf{m l})$} \\
\cline { 2 - 4 } & Retention time $(\mathbf{R t})$ & Peak area & \% Assay \\
\hline 1 & 2.90 & 2109429 & 100.01 \\
2 & 2.930 & 2109837 & 99.99 \\
3 & 2.839 & 2109941 & 99.98 \\
4 & 2.914 & 2107535 & 100.09 \\
5 & 2.845 & 2108530 & 100.05 \\
6 & 2.872 & 2119528 & 99.53 \\
Mean & & 2110800 & 99.94 \\
SD & & 4371.18 & 0.206 \\
RSD & & 0.207 & 0.206 \\
\hline
\end{tabular}

Table 3: Method Precision of Sulphadoxine

\begin{tabular}{|c|c|c|c|}
\hline Sno & Sulphadoxine $(25 \mu \mathrm{g} / \mathrm{ml})$ & & \\
\hline & Retention time(Rt) & Peak area & \% Assay \\
\hline 1 & 6.828 & 14482536 & 99.99 \\
\hline 2 & 6.823 & 14481829 & 100.00 \\
\hline 3 & 6.729 & 14599259 & 99.19 \\
\hline 4 & 6.799 & 14499743 & 99.87 \\
\hline 5 & 6.712 & 14481539 & 100.00 \\
\hline 6 & 6.722 & 14481645 & 100.00 \\
\hline Mean & & 14504425 & 99.84 \\
\hline SD & & 47005.99 & 0.3220 \\
\hline RSD & & 0.324 & 0.3225 \\
\hline
\end{tabular}




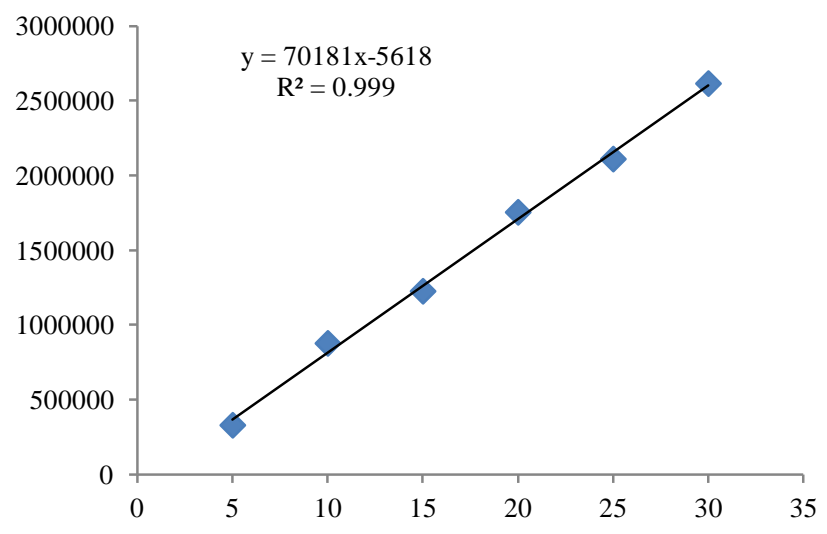

Fig. 2: Linearity of pyrimethamine.

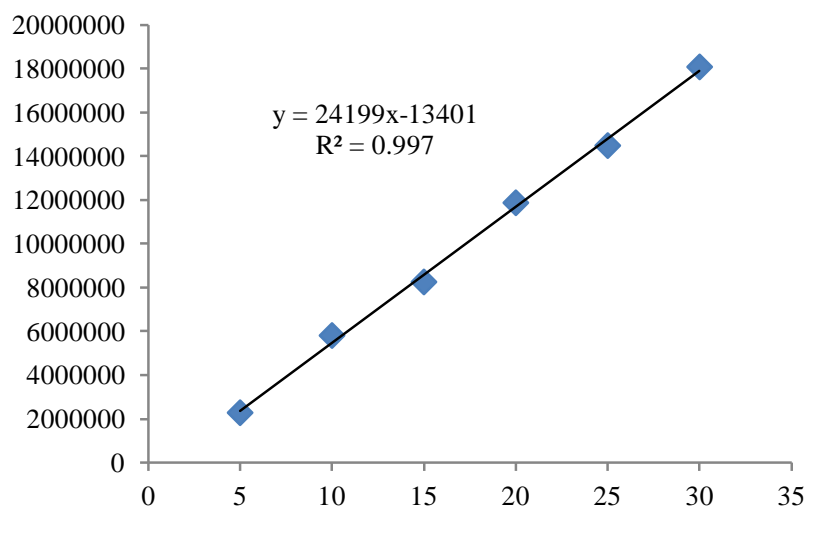

Fig. 3: Linearity of sulphadoxine.

\section{Intermediate Precision}

Intermediate precision of the analytical method was determined by performing method precision on in three successive days by different analysts under same experimental condition. Assay of all six replicate sample preparations was determined and the mean \% RSD of pyrimethamine and sulphodixime was found to be 0.259 and 0.353 respectively (shown in table no 4 ).

Table 4: Intermediate Precision of pyrimethamine \& sulphadoxine.

\begin{tabular}{cccccc}
\hline \multirow{2}{*}{ S.No } & Parameter & & \% RSD & \multicolumn{2}{c}{$\begin{array}{c}\text { Mean } \\
\text { RSD }\end{array}$} \\
\cline { 3 - 6 } & & Day-1 & Day-2 & Day-3 & \\
\hline Pyrimethamine & Peak Area & 0.199 & 0.264 & 0.318 & 0.260 \\
$(\mathbf{2 5} \boldsymbol{\mu g} / \mathbf{m l})$ & \% Assay & 0.198 & 0.263 & 0.317 & 0.259 \\
\hline sulphadoxine & Peak Area & 0.317 & 0.288 & 0.462 & 0.356 \\
$(\mathbf{2 5} \boldsymbol{\mu g} / \mathbf{m l})$ & \% Assay & 0.315 & 0.287 & 0.4584 & 0.353 \\
\hline
\end{tabular}

\section{Accuracy}

Accuracy of the method was established by performing recovery studies according to the $\mathrm{ICH}$ guidelines. Spiked samples were prepared by spiking pre-analyzed sample solutions with pure drug at three different concentration levels each in triplicate. Mean percentage recovery values at three different concentrations of the two drugs was calculated. The \% recovery of Pyrimethamine (98.02-100.45\%) \& Sulphadoxine (99.79-100.20\%) at each level was within the limits of $98 \%$ and $102 \%$ (shown in table no 5\&6).
Hence, accuracy was established for the present work and the method was said to be accurate.

Table 5: \% recovery of Pyrimethamine.

\begin{tabular}{cccccc}
\hline S.no & $\begin{array}{c}\text { Conc }(\boldsymbol{\mu g} / \\
\mathbf{m l})\end{array}$ & $\begin{array}{c}\text { Conc }(\boldsymbol{\mu g} / \mathbf{m l}) \\
\text { found }\end{array}$ & $\begin{array}{c}\text { \% } \\
\text { recovery }\end{array}$ & $\begin{array}{c}\text { Mean } \\
\text { accuracy }\end{array}$ & \% RSD \\
\hline 1 & 15 & 14.8 & 101.35 & & \\
2 & 15 & 15.1 & 99.34 & 100.45 & 1.024 \\
3 & 15 & 14.9 & 100.67 & & \\
\hline 4 & 20 & 20.3 & 98.52 & & \\
5 & 20 & 19.7 & 101.52 & 98.02 & 1.530 \\
6 & 20 & 20.1 & 99.50 & & \\
\hline 7 & 25 & 25.2 & 99.21 & & \\
8 & 25 & 24.9 & 100.40 & 100.14 & 0.832 \\
9 & 25 & 24.8 & 100.81 & & \\
\hline
\end{tabular}

Table 6: \% Recovery of Sulphadoxine

\begin{tabular}{cccccc}
\hline Sno & $\begin{array}{c}\text { Conc } \\
(\boldsymbol{\mu g} / \mathbf{m l})\end{array}$ & $\begin{array}{c}\text { Conc }(\boldsymbol{\mu g} / \mathbf{m l}) \\
\text { found }\end{array}$ & $\begin{array}{c}\% \\
\text { recovery }\end{array}$ & $\begin{array}{c}\text { Mean } \\
\text { accuracy }\end{array}$ & \% RSD \\
\hline 1 & 15 & 14.91 & 100.60 & & \\
2 & 15 & 15.11 & 99.27 & & \\
3 & 15 & 14.89 & 100.74 & 100.20 & 0.811 \\
\hline 4 & 20 & 20.12 & 99.40 & & \\
5 & 20 & 19.89 & 100.55 & & \\
6 & 20 & 20.12 & 99.40 & 99.79 & 0.664 \\
\hline 7 & 25 & 25.09 & 99.64 & & \\
8 & 25 & 25.1 & 99.60 & & \\
9 & 25 & 24.91 & 100.36 & 99.87 & 0.428 \\
\hline
\end{tabular}

\section{Limit of Detection \& Quantification}

In the present study, the LOD and LOQ were calculated according to the standard deviation of the response and the slope of the calibration curve i.e., $3.3 \sigma / \mathrm{S}$ and $10 \sigma / \mathrm{S}$ criterions, respectively; where $\sigma$ is the standard deviation of $y$-intercepts of regression lines and $\mathrm{S}$ is the slope of the calibration curve. The lowest possible concentration of Pyrimethamine that can be detected and quantified by the present method was found to be $0.264 \mu \mathrm{g} / \mathrm{ml}$ and $0.800 \mu \mathrm{g} / \mathrm{ml}$ respectively and that of Sulphadoxine was found to be $0.53 \mu \mathrm{g} / \mathrm{ml}$ and $1.62 \mu \mathrm{g} / \mathrm{ml}$ respectively.

\section{Robustness}

Robustness of the proposed method was determined by varying various parameters, the \% RSD reported was found to be less than $2 \%$.As the system suitability parameters for the standard and test chromatograms of Pyrimethamine \& Sulphadoxine were within limits for variation in flow rate $( \pm 0.1 \mathrm{ml})$ and mobile phase composition, the allowable variation in flow rate, organic solvent ratio in mobile phase composition and column temperature should be $1 \pm 0.1 \mathrm{ml} / \mathrm{min}, 65 \pm 2 \mathrm{ml}$ and $30 \pm 5^{\circ} \mathrm{c}$ respectively (shown in table no $7 \& 8)$.

\section{STRESS DEGRADATION STUDIES}

Stress degradation studies were performed as per the ICH guidelinesQ1A (R2) Stability Testing of New Drug Substances and Products, using the proposed validated analytical method and the results were shown in table no $9 \& 10$. 
Table 7: Robustness of Sulphadoxine

\begin{tabular}{|c|c|c|c|c|c|c|}
\hline \multirow{2}{*}{ Parameter } & \multicolumn{2}{|c|}{ Variation in flow } & \multicolumn{2}{|c|}{ Variation in Mobile phase } & \multicolumn{2}{|c|}{ Variation in column temp } \\
\hline & $\begin{array}{c}\text { flow rate } \\
0.9 \mathrm{mbim} / \mathrm{m}\end{array}$ & flow rate & Buffer:Acetonitrile (75:25) & Buffer:Acetonitrile (80:20) & $30-5^{0}$ & $30+5^{0}$ \\
\hline 1 & 9709676 & 8894030 & 8990708 & 9020771 & 8962774 & 8921543 \\
\hline 2 & 9721151 & 8862782 & 8982909 & 9025663 & 8965300 & 8925743 \\
\hline Mean & 9715414 & 8878406 & 8986809 & 9023217 & 8965537 & 8922143 \\
\hline SD & 8114.7 & 22095.7 & 5515 & 2044.6 & 3163.4 & 2262.4 \\
\hline$\%$ RSD & 0.1 & 0.2 & 0.1 & 0.1 & 0.1 & 0.1 \\
\hline Retention time & 7.09 & 2.715 & 6.03 & 7.07 & 6.47 & 6.37 \\
\hline Tailing factor & 1.33 & 1.33 & 1.32 & 1.3 & 1.32 & 1.43 \\
\hline Theoretical plates & 5217 & 5082 & 5089 & 5306 & 5253 & 5346 \\
\hline
\end{tabular}

Table 8: Robustness of Pyrimethamine.

\begin{tabular}{|c|c|c|c|c|c|c|}
\hline \multirow{2}{*}{ Parameter } & \multicolumn{2}{|c|}{ Variation in flow } & \multicolumn{2}{|c|}{ Variation in Mobile phase } & \multicolumn{2}{|c|}{ variation in column temp } \\
\hline & $\begin{array}{c}\text { flow rate } \\
(0.9 \mathrm{ml} / \mathrm{mim})\end{array}$ & $\begin{array}{c}\text { flow rate } \\
(1.1 \mathrm{ml} / \mathrm{mim})\end{array}$ & Buffer:Acetonitrile (75:25) & Buffer:Acetonitrile (80:20) & $30-5^{0}$ & $30+5^{0}$ \\
\hline 1 & 1588766 & 1485375 & 1435845 & 1539898 & 1454227 & 1434907 \\
\hline 2 & 1603920 & 1484112 & 1425867 & 1549198 & 1480862 & 1440355 \\
\hline Mean & 1596343 & 1484743 & 1430856 & 1544548 & 1467545 & 1437631 \\
\hline SD & 10715 & 892.8 & 7055.5 & 6576.4 & 18833.7 & 3852.6 \\
\hline \% RSD & 0.7 & 0.1 & 0.4 & 0.4 & 1.3 & 0.3 \\
\hline Retention time & 2.95 & 2.715 & 2.43 & 3.076 & 2.71 & 2.66 \\
\hline Tailing factor & 1.47 & 1.44 & 1.42 & 1.39 & 1.44 & 1.43 \\
\hline Theoretical plates & 3679 & 3665 & 3797 & 3824 & 3746 & 3981 \\
\hline
\end{tabular}

Table 9: Results of stress degradation studies of Sulphadoxine.

\begin{tabular}{|c|c|c|c|c|}
\hline Sno & Stress conditions & Time & \% Assay & $\%$ Degradation \\
\hline 1 & Acid Degradation & $30 \mathrm{~min}$ & 88.082 & 11.918 \\
\hline 2 & Base Degradation & $30 \mathrm{~min}$ & 87.281 & 12.719 \\
\hline 3 & Peroxide Degradation & $30 \mathrm{~min}$ & 93.214 & 6.786 \\
\hline 4 & UV Degradation & 7 days & 92.887 & 7.113 \\
\hline
\end{tabular}

Table 10: Results of stress degradation studies of Pyrimethamine.

\begin{tabular}{|c|c|c|c|c|}
\hline Sno & Stress conditions & Time & \% Assay & \% Degradation \\
\hline 1 & Acid Degradation & $30 \mathrm{~min}$ & 92.713 & 7.287 \\
\hline 2 & Base Degradation & $30 \mathrm{~min}$ & 85.985 & 14.015 \\
\hline 3 & Peroxide Degradation & $30 \mathrm{~min}$ & 82.798 & 17.202 \\
\hline 4 & UV Degradation & 7 days & 93.502 & 6.498 \\
\hline
\end{tabular}

\section{Acid degradation studies}

To $1 \mathrm{ml}$ of stock solution pyrimethamine and sulphadoxine, $1 \mathrm{ml}$ of $2 \mathrm{~N} \mathrm{HCl}$ was added and refluxed for $30 \mathrm{~min}$ at $60^{\circ} \mathrm{c}$. From the above solution $10 \mu \mathrm{l}$ was injected into the system and the chromatograms were recorded to detect the stability of sample (figure 4).

\section{Alkali Degradation Studies}

To $1 \mathrm{ml}$ of stock solution of of standard drug and sample pyrimethamine and sulphadoxine, $1 \mathrm{ml}$ of $2 \mathrm{~N} \mathrm{NaOH}$ was added and refluxed for $30 \mathrm{~min}$ at $60{ }^{\circ} \mathrm{C}$. From the above solution $10 \mu \mathrm{l}$ was injected into the system and the chromatograms were recorded to detect the stability of sample (figure 5).

\section{Oxidation}

To $1 \mathrm{ml}$ of stock solution of standard drug and sample of pyrimethamine and sulphadoxine, $1 \mathrm{ml}$ of $20 \% \mathrm{H}_{2} \mathrm{O}_{2}$ was added and refluxed for $30 \mathrm{~min}$ at $60^{\circ} \mathrm{c}$. From the above solution $10 \mu \mathrm{l}$ was injected into the system and the chromatograms were recorded to detect the stability of sample (figure 6).
Photo Stability Studies

The photochemical stability of the drug was also studied by exposing the $25 \mu \mathrm{g} / \mathrm{ml}$ solution to UV Light by keeping the beaker in UV Chamber for 7days or 200 Watt hours $/ \mathrm{m}^{2}$ in photo stability chamber . For HPLC study, from the above solution $10 \mu \mathrm{l}$ was injected into the system and the chromatograms were recorded to detect the stability of sample (figure 7).

Pyrimethamine and Sulphadoxine undergoes degradation in acidic, oxidation, alkaline, and UV. More degradation was found for oxidation. As per ICH guidelines peak purity angle should be less than peak purity threshold. Hence, method of the analysis of PYR and SUL in tablet dosage form shows that the degradation product doesn't interfere with the analytical determination. The stress degradation studies showed that the drug formulation containing pyrimethamine and sulphadoxine undergoes degradation in acidic, oxidation, alkaline, and UV (7.29\% $, 15.01 \%, 16.13 \%, 7.88 \%, 5.51 \%$ and $12.92 \%, 10.72 \%$, $7.13 \%, 13.32 \%, 6.01 \%)$. hence the proposed analytical method is also useful for the determination of pyrimethamine and sulphadoxine stability in sample of pharmaceutical dosage form. 


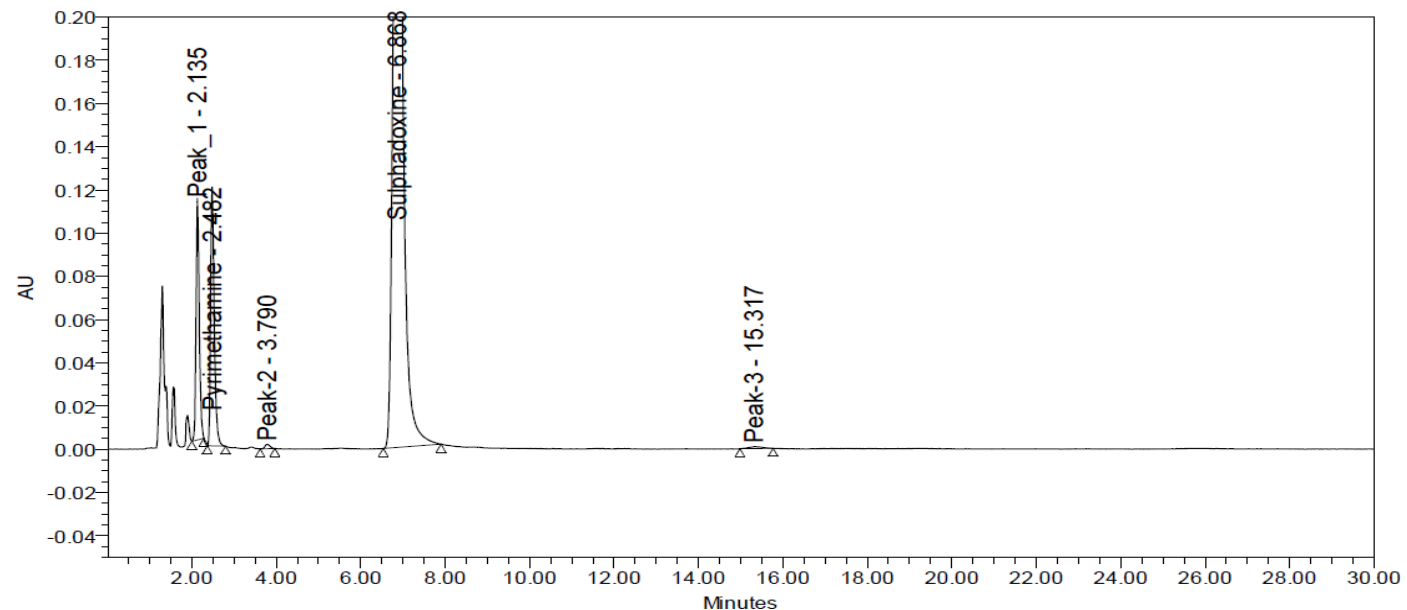

Fig. 4: Chromatogram for Sample acid degradation.

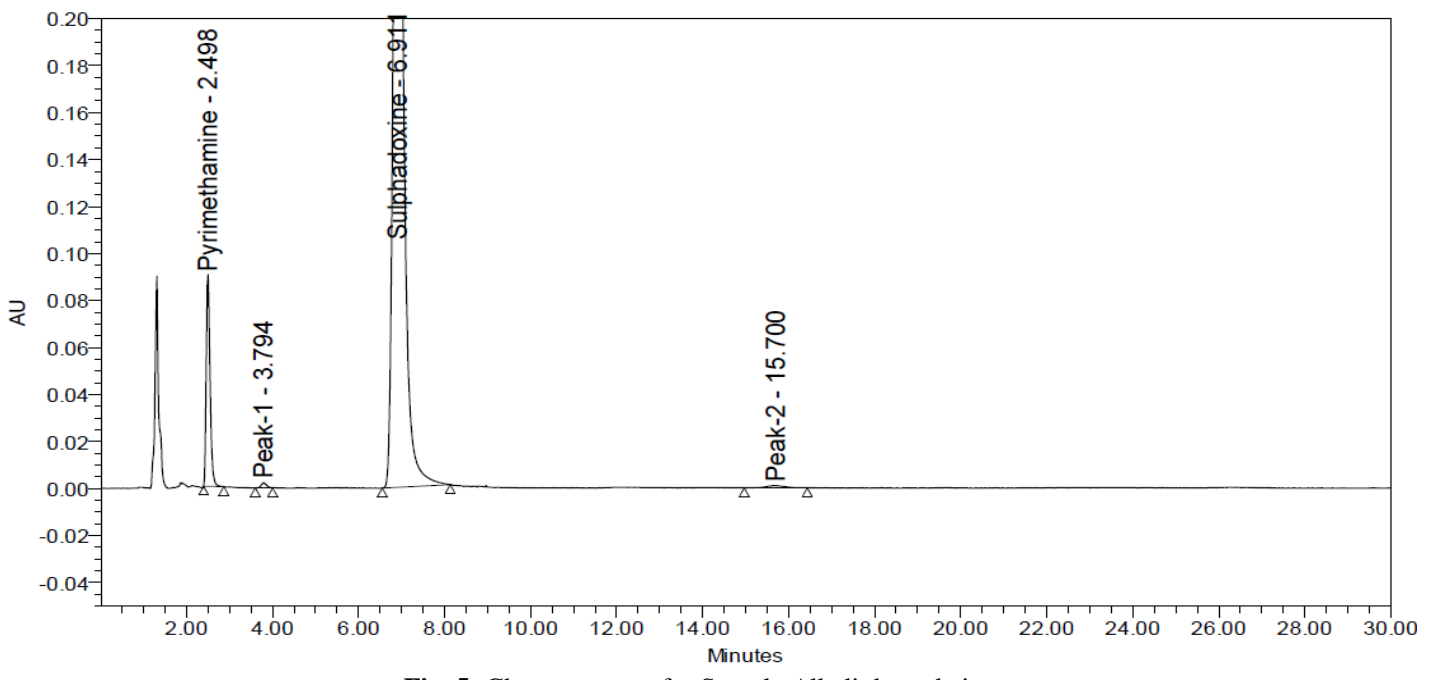

Fig. 5: Chromatogram for Sample Alkali degradation.

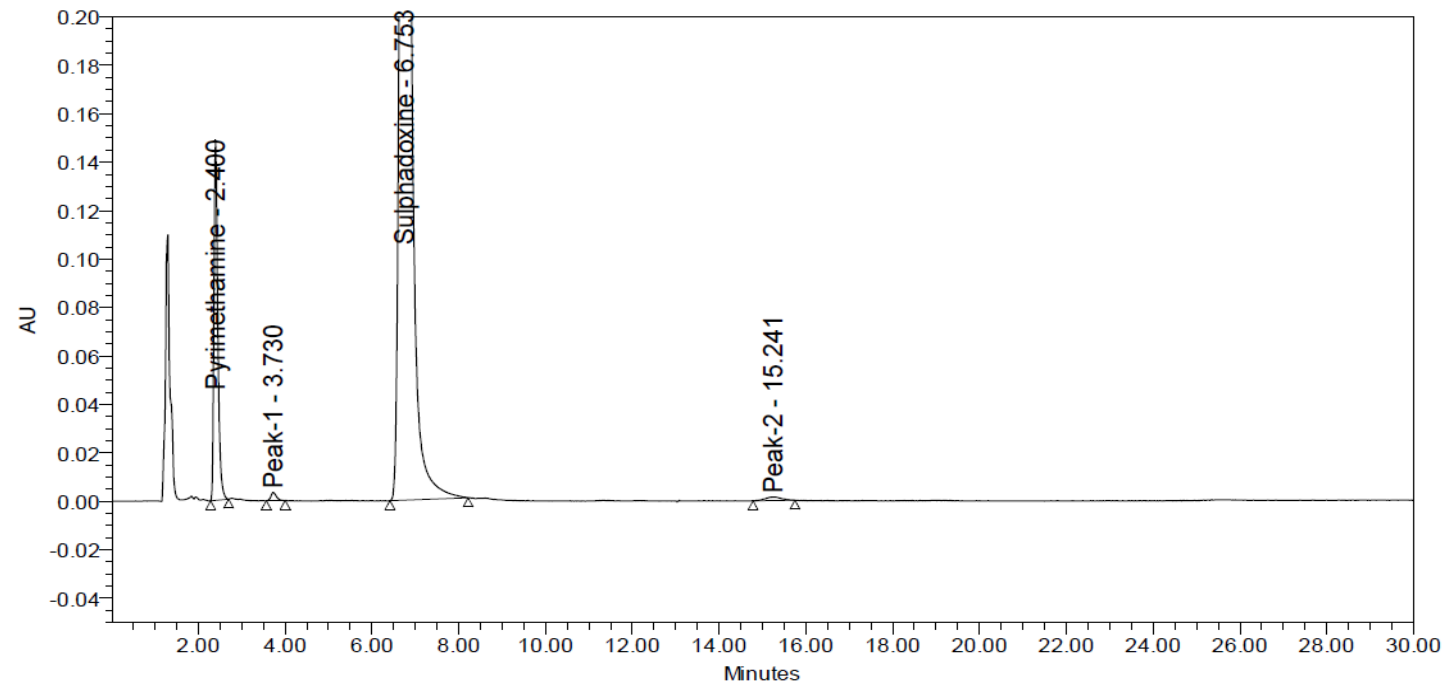

Fig. 6: Chromatogram for Sample Peroxide degradation. 


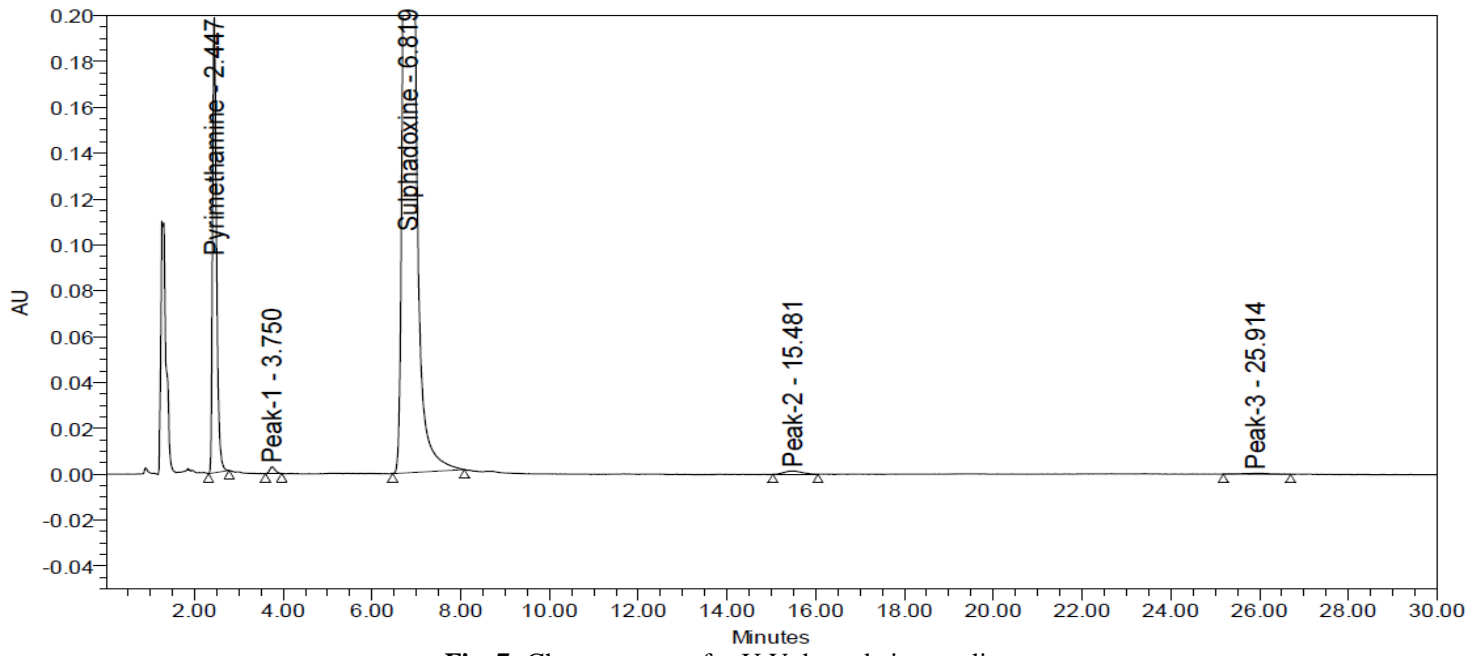

Fig. 7: Chromatogram for U.V degradation studies.

\section{CONCLUSION}

The proposed HPLC method was found to be simple, specific, precise, accurate, rapid and economical for simultaneous estimation of pyrimethamine \& sulphadoxine in bulk and tablet dosage form and was found to be suitable for the routine analysis and quality control and percentage degradation of pharmaceutical preparations containing these drugs either individually or in combination.

\section{REFERENCES}

Amin NC, Blanchin MD, Aké M, Fabre H. Capillary zone electrophoresis as a potential technique for the simultaneous determination of sulfadoxine and pyrimethamine in tablet formulations. J Pharm Biomed Anal, 2012; 58:168-71.

Astier H, Renard C, Cheminel V, Soares O, Mounier C, Peyron F et al., Simultaneous determination of pyrimethamine and sulphadoxine in human plasma by high-performance liquid chromatography after automated liquid-solid extraction. J Chromatogr B: Biomed Sci Appl, 1997; 698(1-2):217-23.

Bergqvist $\mathrm{Y}$, Eckerbom S, Larsson $\mathrm{H}$, Malekzadeh $\mathrm{M}$. Reversed-phase liquid chromatographic method for the simultaneous determination of the antimalarial drugs sulfadoxine, pyrimethamine, mefloquine and its major carboxylic metabolite in plasma. J Chromatogr, 1991; 571(1-2):169-77.

Bergqvist Y, Eriksson M. Simultaneous determination of pyrimethamine and sulphadoxine in human plasma by high-performance liquid chromatography. Trans R Soc Trop Med Hyg, 1985; 79(3):297301 .

Green MD, Mount DL, Nettey H. High-performance liquid chromatographic assay for the simultaneous determination of sulfadoxine and pyrimethamine from whole blood dried onto filter paper. J Chromatogr B AnalytTechnol Biomed Life Sci, 2002; 767 (1):159-62.

Meena S, Sandhya SM. Validated HPTLC Method for Simultaneous Analysis of Pyrimethamine and Sulphadoxine in Pharmaceutical Dosage Forms. Journal of Chemistry, 2013:1 - 6.

Meena S, Sandhya SM. Validated spectrophotometric methods for simultaneous analysis of pyrimethamine and sulphadoxine in pharmaceutical dosage forms. Asian J Pharm Clin Res, 2013; 6(3): 121123.

Minzi OM, Massele AY, Gustafsson LL, Ericsson O.Simple and cost-effective liquid chromatographic method for determination of pyrimethamine in whole blood samples dried on filter paper. J Chromatogr B: Analyt Technol Biomed Life Sci, 2013; 814(1):179-183.

Onah JO, Odeiani JE. Simultaneous spectrophotometric determination of sulfadoxine and pyrimethamine in pharmaceutical formulations. J Pharm Biomed Anal, 2002; 30(3):851-7.

SaeedArayne M, Najma Sultana, Farhan Ahmed Siddiqui, SajidaNaseem, Faiza Qureshi. Simultaneous determination of pyrimethamine, sulfadoxine, mefloquine, and ibuprofen in pharmaceutical formulations by RP-HPLC. Medicinal Chemistry Research, 2010; 19(9):1043-1054

Sinnaeve BA, Decaestecker TN, Risha PG, Remon JP, Vervaet C, Van Bocxlaer JF. Liquid chromatographic-mass spectrometric assay for simultaneous pyrimethamine and sulfadoxine determination in human plasma samples. J Chromatogr A, 2005; 1076(1-2):97-102.

\section{How to cite this article:}

Anil Kumar V, Sindgi VM, Satla SR, Thimmaraju MK. Stability Indicating Rp-Hplc Method for the Simultaneous Estimation of Pyrimethamine and Sulphadoxine in Bulk and Tablet Dosage Form. J App Pharm Sci, 2016; 6 (03): 071-076. 